\title{
UNA NOTA SOBRE ESCULTURA CASTELLANA DEL SIGLO XIII: JUAN GONZÁLEZ, EL PINTOR DE LAS IMÁGENES DE BURGOS, Y EL SEPULCRO DE DOÑA MAYOR GUILLÉN DE GUZMÁN EN EL CONVENTO DE SANTA CLARA DE ALCOCER (GUADALAJARA)*
}

\author{
Fernando GutiérRez Baños \\ Universidad de Valladolid
}

En 2009 Christie's de Londres dio a conocer el contrato del sepulcro de doña Mayor Guillén de Guzmán († c. 1263), antigua amante del rey Alfonso X el Sabio. El contrato procede del convento de Santa Clara de Alcocer (Guadalajara), donde el propio sepulcro se conservó hasta su completa destrucción en 1936 al estallar la Guerra Civil. Datado en Burgos en 1276, el documento nos proporciona una completa descripción de la obra a realizar. Esto nos permitirá compararla con otros sepulcros contemporáneos, subrayando los rasgos altamente innovadores del sepulcro de doña Mayor. Por otra parte, el documento nos permitirá acceder a la personalidad del artista responsable de la obra: un cierto Juan González, desconocido hasta la fecha, que se presenta como el pintor de las imágenes de Burgos.

Palabras clave: Escultura gótica; Sepulcro; Juan González; Mayor Guillén de Guzmán; Alcocer.

\section{A NOTE ON $13^{\text {TH }}$ CENTURY CASTILIAN SCULPTURE: JUAN GONZÁLEZ, EL PINTOR DE LAS IMÁGENES DE BURGOS, AND THE TOMB OF DOÑA MAYOR GUILLÉN DE GUZMÁN IN THE CONVENT OF POOR CLARES OF ALCOCER (GUADALAJARA)}

In 2009 Christie's London brought to light the contract for the tomb of doña Mayor Guillén de Guzmán († c. 1263), former mistress of king Alfonso X the Wise. The contract comes from the convent of Poor Clares

\footnotetext{
* Este artículo se enmarca en el proyecto de investigación Cultura visual y cultura libraria en la Corona de Castilla (1284-1350) III, financiado por el Ministerio de Economía y Competitividad (referencia HAR2012-34876) y en el G.I.R. IDINTAR: Identidad e Intercambios Artísticos. De la Edad Media al mundo contemporáneo. La labor bibliográfica pudo ser completada merced a una ayuda del plan de movilidad de personal investigador de la Universidad de Valladolid, cofinanciada por el Banco de Santander, de la que disfruté en 2013 en calidad de Visiting Fellow en el Index of Christian Art (Department of Art and Archaeology) de la Princeton University. Este artículo es, asimismo, el producto de la amistad y de la generosidad de Javier Docampo, del Museo Nacional del Prado, y de mis compañeros de la Universidad de Valladolid Irene Ruiz y Mauricio Herrero, del área de Ciencias y Técnicas Historiográficas, y Francisco Morillo, responsable del tratamiento de las imágenes, del Laboratorio de Fotogrametría Arquitectónica. Elaborado ya este trabajo, Arbesú, 2013, ha publicado un estudio y edición del contrato del sepulcro de doña Mayor Guillén de Guzmán que es el eje de mi artículo. Agradezco a Archivo Español de Arte la oportunidad que me brinda de dar a conocer mi propia lectura del documento.
} 
of Alcocer (Guadalajara), where the tomb itself remained until completely destroyed in 1936 at the beginning of the Spanish Civil War. Dated in Burgos in 1276, the document provides a full description of the work to be carried out. This allows us to compare it with other contemporary tombs, underlining the highly innovative features of that created for doña Mayor. In addition, the document provides access to the personality of the artist responsible for this work: a certain until now unknown Juan González, who introduces himself as el pintor de las imágenes de Burgos ('the painter of images of Burgos').

Key words: Gothic sculpture; Tomb; Juan González; Mayor Guillén de Guzmán; Alcocer.

El 23 de noviembre de 2009 Christie's de Londres vendía en subasta un contrato datado en Burgos en 1276 por el que Juan González, el pintor de las imágenes de Burgos, se comprometía a fabricar el sepulcro de doña Mayor Guillén de Guzmán, antigua amante de Alfonso X el Sabio $^{1}$. Se trata de un documento excepcional ${ }^{2}$, relacionable con un monumento funerario que existió, en efecto, en el convento de Santa Clara de Alcocer, fundado por esta señora, el cual

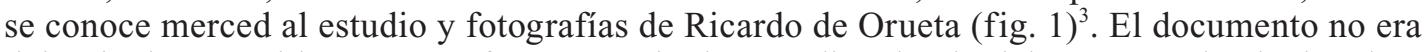
del todo desconocido. En 1656 fray Gregorio de Heredia, vicario del convento damianita alcarreño, compuso un manuscrito que se conoce como Quaderno en el cual recopiló un índice de los documentos del archivo conventual. Este manuscrito fue copiado en 1720 y fue analizado a finales del siglo XIX por Juan Catalina García, quien mencionó entre los documentos reseñados en el mismo "Una obligación de un pintor que este hizo a un capellán de $\mathrm{D}^{\mathrm{a}}$ Beatriz para fabricar y pintar el sepulcro de la fundadora"4. Así pues, a mediados del siglo XVII el documento se encontraba en el archivo del convento de Santa Clara de Alcocer. Cuál fuera su suerte posterior hasta su aparición en el mercado de arte en 2009 es algo que, por desgracia, no podemos precisar ${ }^{5}$.

El contrato (v. apéndice documental) presenta la estructura típica de este tipo de documentos. Tras un encabezamiento que introduce a las partes contratantes, detalla las características de la obra a realizar (un sepulcro de madera policromada con gran despliegue iconográfico), estableciendo, a continuación, su precio y forma de pago antes de enumerar las garantías ofrecidas por ambas partes, con la especificación del plazo de entrega. Se cierra con la data y testigos. Las partes son, por un lado, Juan González, vecino del barrio de Santa María de Vejarrúa de Burgos, y, por otro lado, don Juan Pérez, capellán de doña Beatriz, reina de Portugal, hija natural de Alfonso X y de la destinataria del sepulcro, que sería la auténtica comitente del enterramiento. Entre los testigos que comparecen están don Pere de Montresín y don Bartolomé de Montresín, a quienes se encontrará de nuevo en las cuentas de Sancho IV del periodo 1292-94 (Bartolomé de Montresín,

\footnotetext{
${ }^{1}$ Venta 5829 (Fine Printed Books, Manuscripts, Traditional Sports), lote 111, v. http://www.christies.com/lotfinder/booksmanuscripts/contract-for-the-tomb-of-dona-mayor-5267930-details.aspx (consultado el 27 de enero de 2014). El documento fue adquirido por la Hispanic Society of America por 10.000 libras esterlinas. Se trata de un documento original, escrito en gótica cursiva en pergamino de 340 x $318 \mathrm{~mm}$. La versión impresa del catálogo de la subasta incluye en su contraportada la fotografía del documento a partir de la cual se ha realizado este estudio.

${ }^{2}$ De hecho, en la Corona de Castilla conozco, únicamente, otro contrato para el periodo anterior a 1400: el firmado en Brihuega en 1387 para la ejecución del retablo mayor de la catedral de Toledo, conservado gracias a una fuente valenciana. Esta circunstancia complica extraordinariamente la realización de estudios sobre el mercado del arte en Castilla, posibles, en cambio, por su riqueza documental, en la Corona de Aragón, de los cuales es un buen ejemplo García Marsilla, 2009

3 Orueta, 1919: 5-21.

${ }^{4}$ García, 1899: 596-599 (núm. 1359).

${ }^{5}$ Juan Catalina García lo buscó infructuosamente en el Archivo Histórico Nacional y en la Delegación de Hacienda de Guadalajara, v. Relaciones topográficas..., 1903: 155 (n. 3). Sobre la dispersión de la documentación del convento de Santa Clara de Alcocer, v. Martín Prieto, 2010: 21-24.
}

Arch. esp. arte, LXXXVIII, 349, ENERO-MARZO 2015, 37-52 ISSN: 0004-0428, eISSN: 1988-8511, doi: 10.3989/aearte.2015.03 


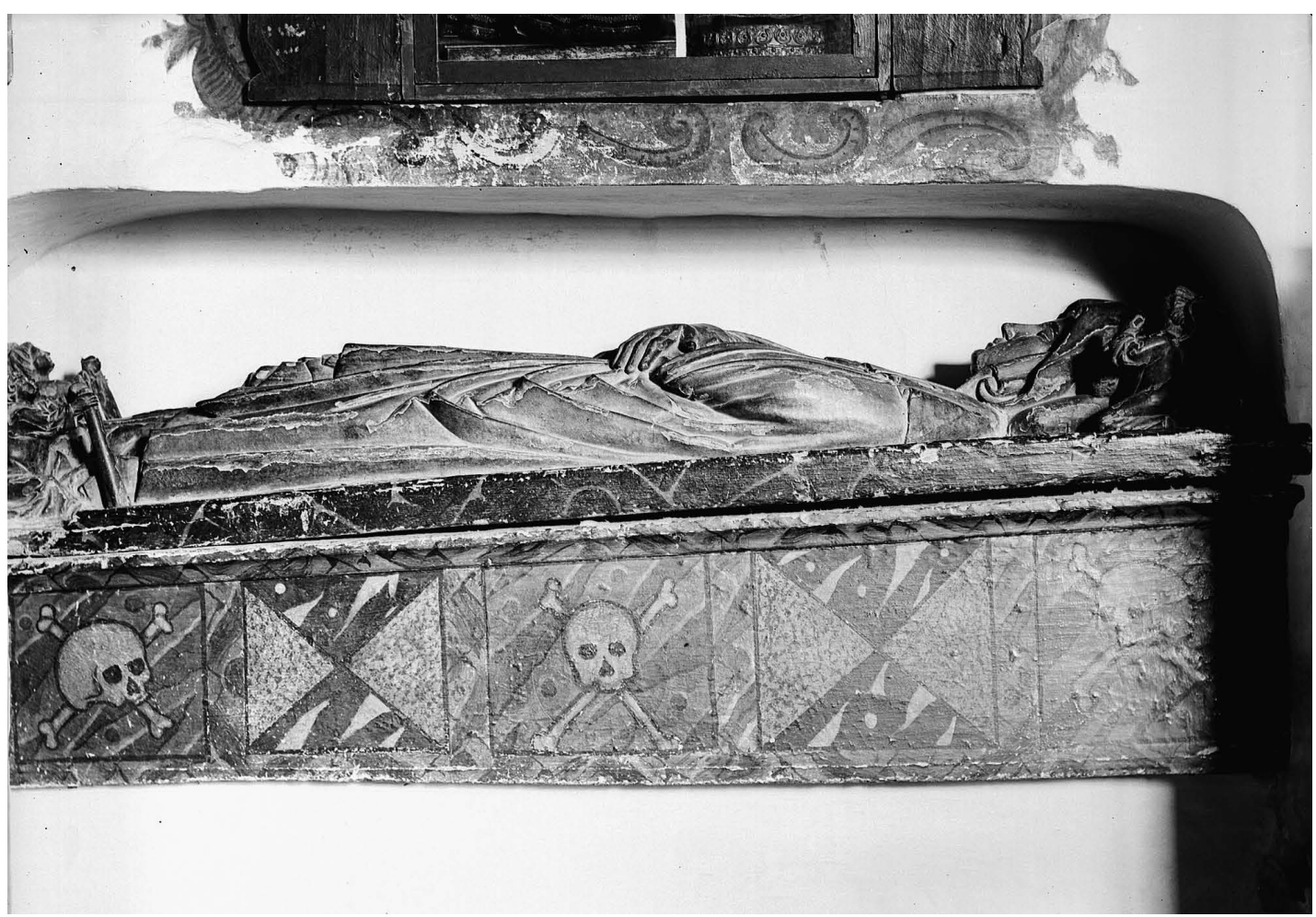

Fig. 1. Alcocer (Guadalajara), convento de Santa Clara: sepulcro de doña Mayor Guillén de Guzmán († c. 1263); foto: Ricardo de Orueta (C) CSIC, Centro de Ciencias Humanas y Sociales, Biblioteca Tomás Navarro Tomás.

especialmente, aparece a menudo vinculado a la hacienda regia y a la gestión de pagos de la casa real $)^{6}$, y Gonzalo Pérez, ermano de don Pablo, el orebze, este seguramente don Pablo de Modova $(† 1283)$, que fundó un aniversario en la catedral de Burgos ${ }^{7}$.

\section{Doña Mayor Guillén de Guzmán y el convento de Santa Clara de Alcocer}

Doña Mayor Guillén de Guzmán se convirtió en amante del joven infante don Alfonso cuando este aún no había ceñido su corona y cuando ni siquiera había contraído matrimonio con quien sería su legítima esposa, la reina doña Violante de Aragón. Fruto de sus relaciones fue, cuando menos, una hija natural, doña Beatriz, a quien su padre desposó en 1253 con Alfonso III de Portugal, convirtiéndola, por tanto, en reina de Portugal. Doña Beatriz mantuvo siempre el contacto con su padre y, ya viuda (desde 1279), regresó a Castilla, acompañándolo en los difíciles años finales de su reinado. Desde el punto de vista sentimental y familiar, doña Mayor y su hija doña Beatriz formaron

\footnotetext{
${ }^{6}$ López Dapena, 1984: 494 (Pedro de Monresín) y 435-436, 492-495, 496-503, 515-517, 548-553 y 614 (Bartolomé de Monresín).

${ }^{7}$ Martínez y Sanz, 1866: 215. Se cita nuevamente a don Pablo, con carácter póstumo, en 1288, v. Castro Garrido y Lizoain Garrido, 1987: 115-117 (núm. 58).
}

Arch. esp. arte, LXXXVIII, 349, ENERO-MARZO 2015, 37-52

ISSN: 0004-0428, eISSN: 1988-8511, doi: 10.3989/aearte.2015.03 
parte del núcleo más íntimo y entrañable del monarca ${ }^{8}$. Consolidado su matrimonio con la reina doña Violante, Alfonso X se ocupó de proporcionar a doña Mayor un retiro honroso, creando para ella un señorío hereditario en torno a Alcocer en $1255^{9}$. Aquí doña Mayor dispuso la fundación de un convento de clarisas, formalizada el 22 de septiembre de 1260 con mandado e con plazer de mio sennor don Alfonso, por la graçia de Dios Rey de Castiella e de Leon ${ }^{10}$.

Doña Mayor Guillén de Guzmán falleció c. 1263, siendo enterrada en el convento de su fundación, para el que pocos años después su hija doña Beatriz, reina de Portugal y ya entonces señora de Alcocer, encargaría el sepulcro monumental que es el objeto de nuestro interés a través de su capellán don Juan Pérez (que antes había sido capellán de doña Mayor), quién sabe si con la mediación del propio Alfonso X, que, cuando se firmó el contrato, se encontraba en Burgos de regreso de la aciaga "ida al imperio"11.

El sepulcro se instalaría en el emplazamiento original del convento de Santa Clara de Alcocer (esto es, en el antiguo despoblado de San Miguel del Monte), allí donde doña Mayor Guillén de Guzmán lo había fundado y edificado. En 1373 las monjas se trasladaron al casco urbano de Alcocer $^{12}$. Nada subsiste de la fábrica que entonces se erigiría, en la cual el sepulcro de la fundadora encontraría nuevo acomodo. La fábrica actual data de la Edad Moderna. En su coro, "a la derecha según se miraba al altar", estuvieron, en un arcosolio, los restos de doña Mayor dentro de un sarcófago groseramente pintado imitando mármol para cuya cubierta se aprovechó, afortunadamente, la imagen yacente del sepulcro que encargara en 1276 la reina de Portuga ${ }^{13}$. Este era ya, cuando menos, el tercer emplazamiento del sepulcro, que a estas alturas se encontraba muy mermado con respecto a sus características originales. Allí lo estudió Ricardo de Orueta y allí pereció cuando se produjo el estallido de la Guerra Civil ${ }^{14}$.

\section{Características del sepulcro contratado en 1276}

El sepulcro que había de elaborar Juan González (y que, a la vista de su único elemento conocido, esto es, de su imagen yacente, elaboró, efectivamente, siguiendo, puntualmente, para ello, las indicaciones del contrato de 1276) se contaría, sin duda, de haberse conservado, entre los más destacados exponentes de la plástica funeraria castellana del siglo XIII. Sus características hermanaban con las de otros dos sepulcros bien conocidos, a saber, el sepulcro de doña Urraca López de Haro, reina viuda de León, en el monasterio cisterciense de Santa María la Real de Vileña, en la comarca burgalesa de La Bureba, y el sepulcro de la Beata de Cañas, homónima de la anterior, en el monasterio cisterciense de esta localidad riojana. Sin embargo, el sepulcro de doña Mayor Guillén de Guzmán presentaba, al mismo tiempo, rasgos singulares e innovadores que hacen tanto más lamentable su pérdida. Como los sepulcros aducidos, el sepulcro alcarreño era un sepulcro femenino de una dama de la más alta prosapia, estrechamente vinculada a la monarquía, concebido para su efectista disposición en un instituto religioso de su promoción, vinculado a

\footnotetext{
${ }^{8}$ González Jiménez, 2004: 28-29.

9 Martín Prieto, 2002-03: 221-223; 2005b: 71-77.

${ }_{10}$ Martín Prieto, 2005a; 2005b: 77-79.

${ }^{11}$ Consta en Burgos entre el 18 de abril y el 26 de julio de 1276, momento en que celebró cortes, v. González Jiménez y Carmona Ruiz, 2012: 79-80.

${ }^{12}$ Martín Prieto, 2007: 66-69.

13 Pérez Arribas, 1974: 64-66, 97-98 y 129-130. Herrera Casado, 1997: 140-144. Pérez Arribas publica una fotografía del arcosolio ya despojado de los restos del sepulcro.

${ }^{14}$ García Martín, 2009: 207-208; García de Paz, 2011: 138-141.
}

Arch. esp. arte, LXXXVIII, 349, ENERO-MARZO 2015, 37-52 ISSN: 0004-0428, eISSN: 1988-8511, doi: 10.3989/aearte.2015.03 


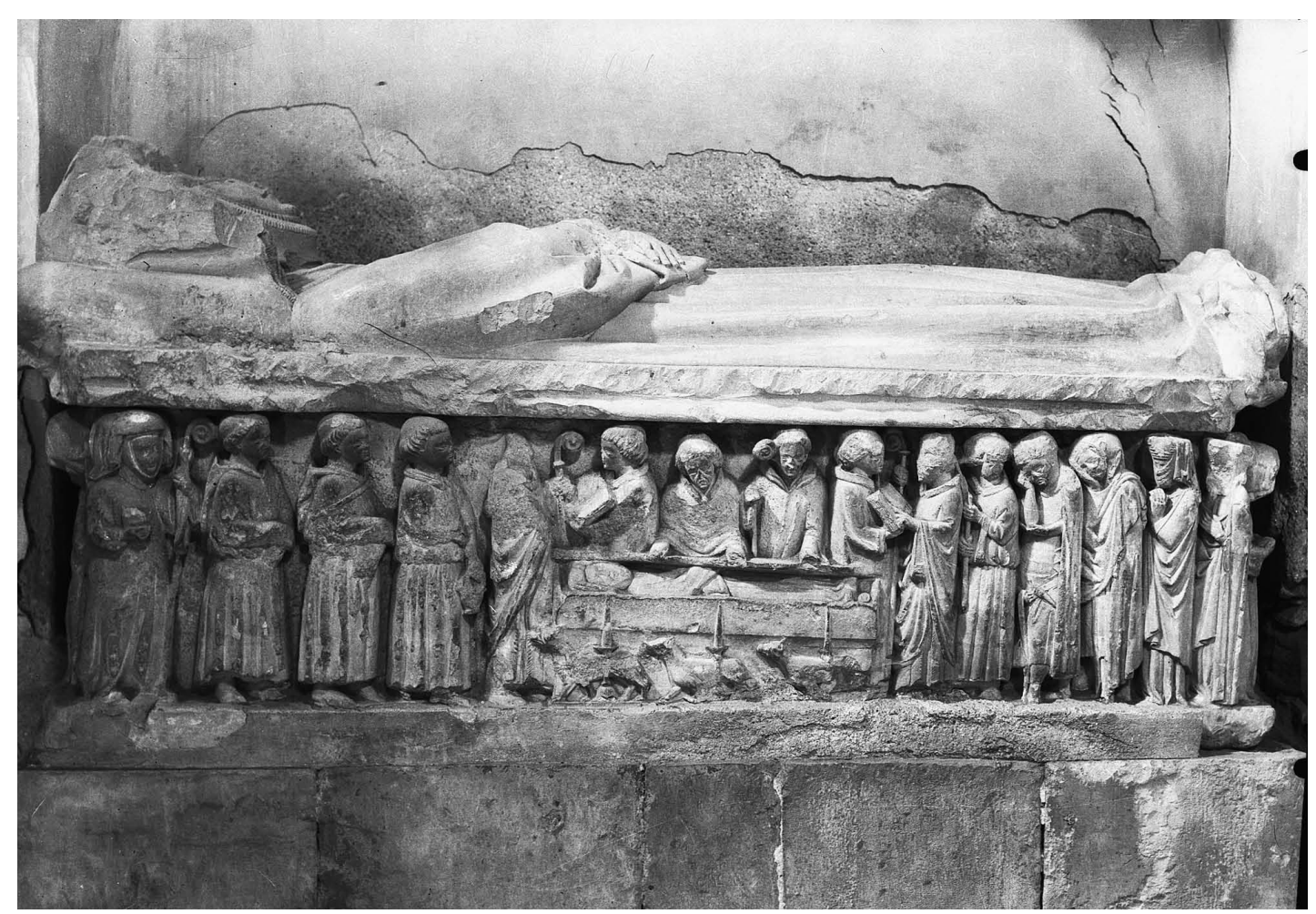

Fig. 2. Vileña (Burgos), monasterio cisterciense de Santa María la Real: sepulcro de doña Urraca López de Haro († entre 1226 y 1230); foto: Gonzalo Miguel Ojeda (Photo Club) (C) Archivo de la Diputación Provincial de Burgos.

sus intereses patrimoniales. Los tres se fabricaron con muy pocos años de diferencia (en relación, probablemente, con Burgos), siendo exponentes, si es que no motores, del salto cualitativo que se produjo en la plástica funeraria castellana del último tercio del siglo XIII.

Doña Urraca López de Haro, tras enviudar de Fernando II en 1188 y tras ver frustradas sus aspiraciones a mediatizar la política leonesa, se retiró a Castilla, donde dispuso la fundación del monasterio de Vileña, el cual se incorporó formalmente a la orden del Císter bajo la autoridad del monasterio burgalés de las Huelgas en 1222. Doña Urraca se retiró a su monasterio, en el que profesó como religiosa, falleciendo en una fecha indeterminada entre 1226 y 1230. Algún tiempo después se fabricó su sepulcro (fig. 2), el cual presidió hasta 1748 la capilla mayor de la iglesia abacial $^{15}$. Como corresponde a un monumento funerario concebido para su disposición exenta en un presbiterio, el sepulcro de doña Urraca López de Haro se encuentra tallado por sus cuatro costados. Su costado izquierdo (según el espectador) muestra con copia de detalles descriptivos el entierro de doña Urraca, al que asisten, amén de gran número de religiosos, sus familiares. Cabe entender como parte de esta representación las monjas presentes en el costado de la cabecera y en el costado de los pies. El mensaje redentor, transmitido mediante un pequeño ciclo de la infancia de Cristo

${ }^{15}$ Sánchez Ameijeiras, 1993: 186-190. Ruiz Maldonado, 1996: 127-133 y 145-147. El sepulcro se encuentra en la actualidad en Burgos, en el Museo del Retablo (iglesia de San Esteban).

Arch. esp. arte, LXXXVIII, 349, ENERO-MARZO 2015, 37-52

ISSN: 0004-0428, eISSN: 1988-8511, doi: 10.3989/aearte.2015.03 


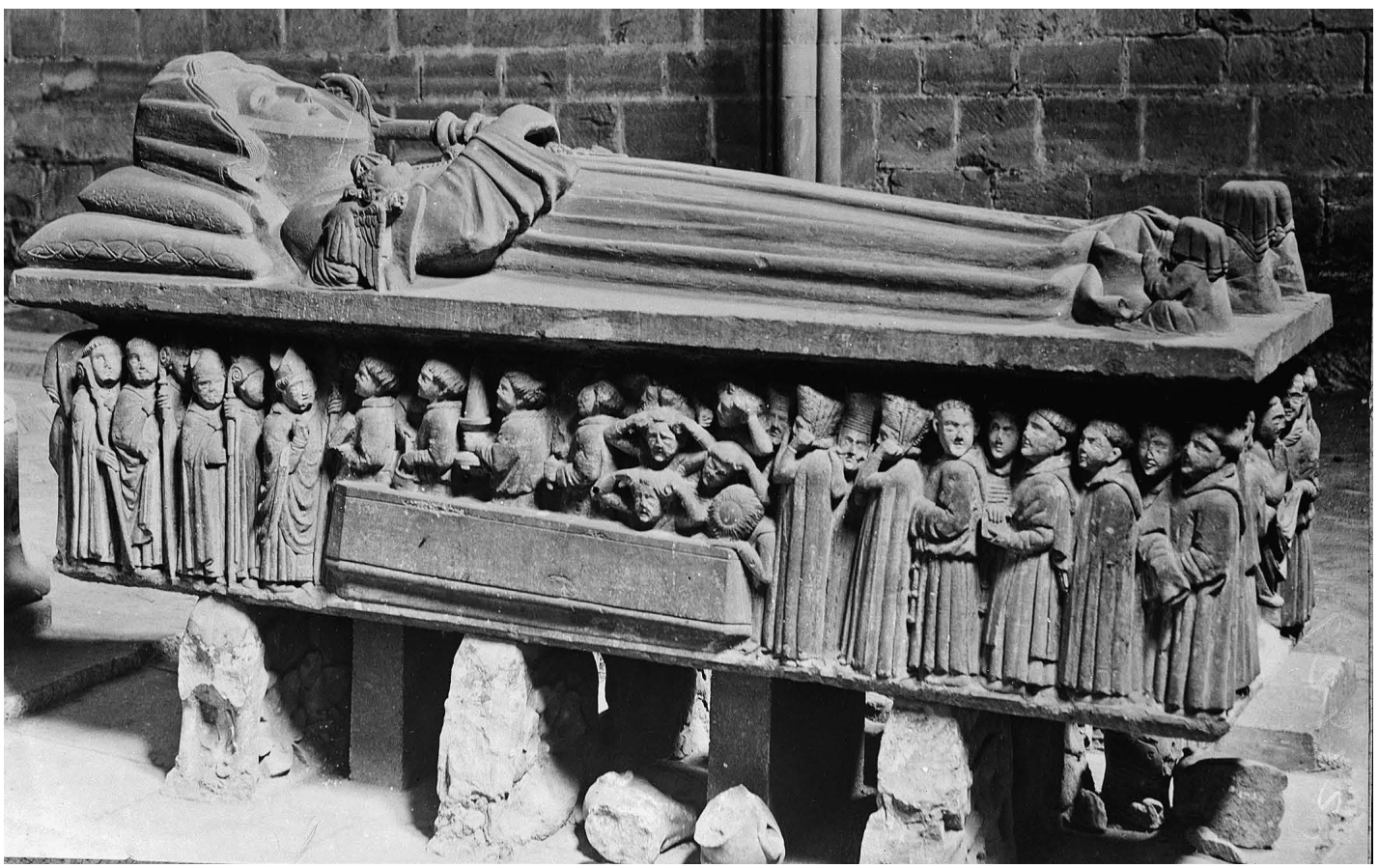

Fig. 3. Cañas (La Rioja), monasterio cisterciense de Santa María del Salvador: sepulcro de la Beata doña Urraca López de Haro $(†$ 1262) (C) Fundación Insituto Amatller de Arte Hispánico, Archivo Mas.

(Anunciación, Visitación y Adoración de los Magos), se confía a su costado derecho. Sobre este sarcófago, la imagen yacente muestra a la reina viuda de León reducida al estado religioso que adoptó, acompañada, a la cabecera, por ángeles turiferarios.

La Beata de Cañas, de problemática identificación, sería, según argumenta Ruiz Maldonado, una condesa homónima de la reina viuda de León (de quien sería sobrina). Tras fallecer su esposo, el conde don Álvar Núñez de Lara, esta segunda doña Urraca López de Haro profesó en el monasterio cisterciense de Santa María del Salvador de Cañas, fundado por sus abuelos a partir del traslado y reconversión en 1169-70 de un antiguo cenobio, convirtiéndose, a partir de 1225, en su cuarta abadesa, (hasta su muerte en 1262). Algún tiempo después se fabricó su sepulcro, que tiene muy presente el precedente del enterramiento de su tía en Vileña, si bien, en este caso, se dispuso, de acuerdo con su dignidad, en la sala capitular, emplazamiento en el que aún se le puede admirar (fig. 3$)^{16}$. Asentado sobre lobos (animales heráldicos de la casa de Haro) y tallado, asimismo, por sus cuatro costados, el sepulcro de la Beata de Cañas concede un mayor protagonismo a la iconografía funeraria en detrimento del ciclo redentor. En cualquier caso, el mensaje salvífico está presente en el relieve del costado de la cabecera, que muestra a San Pedro acogiendo a la abadesa como complemento del relieve del costado de los pies, donde aparece su elevatio animae. Su costado izquierdo (según el espectador) nos ofrece la imagen de los funerales, con gran concurrencia de religiosos y de familiares que, en este caso, frente a la cierta contención exhibida en Vileña, extreman sus expresiones de dolor. El costado opuesto muestra a las monjas de Cañas recibiendo las condo-

\footnotetext{
${ }^{16}$ Ruiz Maldonado, 1996: 117-124 y 146-147.
}

Arch. esp. arte, LXXXVIII, 349, ENERO-MARZO 2015, 37-52 ISSN: 0004-0428, eISSN: 1988-8511, doi: 10.3989/aearte.2015.03 
lencias. Sobre este sarcófago, la imagen yacente muestra el cuerpo exánime de la abadesa con los atributos propios de su condición (y, como elemento novedoso, con un rosario), acompañada, a la cabecera, por ángeles turiferarios y, a los pies, por varias religiosas que velan su cuerpo.

Como los sepulcros de estas dos señoras, el sepulcro de doña Mayor Guillén de Guzmán hubo de ser un sepulcro exento destinado a presidir un espacio privilegiado de la fundación que patrocinó. Así lo ponen de manifiesto el hecho de que se señale que debe reposar sobre seis leones, tres de la vna parte e tres de la otra, y el hecho de que se precisen los relieves que ha de mostrar en sus cuatro costados: a la cabeça... en el vna costera... de la otra parte... a los pies... Pienso que este espacio pudo ser, en origen, el coro del edificio primigenio a las afueras de Alcocer, a la vista del paralelismo que ofrecen ejemplos como los bien conocidos sepulcros de Alfonso VIII y de su esposa la reina doña Leonor de Inglaterra en el monasterio de las Huelgas. La disposición de un baldaquino sobre la sepultura (el tabernáculo de suso que a de cobrir la sepultura), apoyado sobre los seis leones mencionados, resulta excepcional, pero no única: a caballo entre el siglo XII y el siglo XIII se pueden recordar el sepulcro de la iglesia de la Magdalena de Zamora y el llamado sepulcro cuarto del pórtico del monasterio de las Huelgas. Cabe imaginarlo como una estructura lígnea completamente exenta, de acuerdo con las características del sarcófago que había de dignificar, que se decoraría, interiormente (entiendo que mediante pintura), con un Calvario (el Cruciffiçión e la María e el Johán e dos ángeles), el cual, como en tantos otros sepulcros contemporáneos, aportaría el mensaje redentor al discurso iconográfico del monumento fúnebre.

No menor que su originalidad tipológica era su originalidad iconográfica. En efecto, el monumento funerario de doña Mayor Guillén de Guzmán ofrecía motivos novedosos junto a temas comunes como la representación de los ritos y ceremonias que acontecen en torno a la muerte. En ocasiones, estos motivos son conformes con las inquietudes del arte castellano de finales del siglo XIII, patentes en otros monumentos funerarios del periodo, pero, en ocasiones, estos motivos se anticipan en más de un siglo a los derroteros del arte sepulcral. Las escenas correspondientes al duelo y a los funerales distinguían entre la familia "carnal", que se disponía en uno de los costados mayores (carecemos de elementos de juicio para determinar cuál): en el vna costera de la sepultura que sea la rreyna de Portogal e sos fijos e donna Mayor en medio en su lecho e todos vestidos de sus pannos, y la que podríamos llamar "familia social y espiritual" (la comunidad patrocinada por la finada), que se disponía en el otro: de la otra parte de la sepultura (...) el abbadessa e el conuento e sus donzellas e los de criazón e donna Mayor en medio en su lecho e todos cubiertos de sus sennales. Detalles como la precisa elección de los momentos a representar, su secuencia, su desarrollo narrativo... o como la intensidad en la representación del duelo que, sin duda, los acompañaría, parecen quedar al albur del artífice, por lo que no podemos saber cómo se trataron estos motivos tan característicos del arte funerario castellano del siglo XIII ${ }^{17}$, presentes en los sepulcros de sus homólogas. Especialmente interesante sería poder comprobar si en el sepulcro de doña Mayor Guillén de Guzmán estas escenas se ajustaron a la cierta contención propugnada en las Partidas por su amado Alfonso X, aunque el sepulcro, en su conjunto, se aparta del ideal de cierta austeridad que pareció perseguir el monarca ${ }^{18}$.

En la cabecera del sepulcro de doña Mayor Guillén de Guzmán se representaba la imagen de Sancta María e donna Mayor que sea a sos pies en oraçión. Si bien no es el primer ejemplo ${ }^{19}$, pudiéndose poner en paralelo con su estricto contemporáneo el sepulcro del infante don Fernando de la Cerda († 1275), el detalle sirve para matizar, de acuerdo con la espiritualidad de la época, el

\footnotetext{
${ }^{17}$ Gómez Bárcena, 1988b.

18 Yarza Luaces, 1984: 6 y 8. Yarza encuentra un ejemplo del ideal alfonsí en el sepulcro del infante don Fernando de la Cerda en el monasterio de las Huelgas.

${ }^{19}$ Gómez Bárcena, 1988a: 37 (n. 24) señala su presencia, a la cabecera, asimismo, en el llamado sepulcro segundo del pórtico del monasterio de las Huelgas, de principios del siglo XIII.
}

Arch. esp. arte, LXXXVIII, 349, ENERO-MARZO 2015, 37-52

ISSN: 0004-0428, eISSN: 1988-8511, doi: 10.3989/aearte.2015.03 
marcado carácter cristológico de muchos de los sepulcros labrados a lo largo del siglo XIII. Más excepcional resulta la presencia de doña Mayor orante a los pies de la Virgen, aunque se pueden señalar como precedentes para esta composición en un contexto funerario las representaciones de clérigos oferentes de algunos sepulcros leoneses de la primera mitad del siglo XIII.

A los pies del sepulcro de doña Mayor Guillén de Guzmán se mostraría a su titular en so lecho cubierta de los pannos de la orden de Sancta Clara e dos ángeles a la cabeça quel' reciban el alma. La representación del difunto en su lecho mortuorio acompañada por la representación de su elevatio animae en tanto que expresión del deseo de su inmediata incorporación al paraíso es un motivo recurrente en la iconografía funeraria. En este sepulcro resulta notabilísimo, sin embargo, el hecho de que se especifique que doña Mayor Guillén de Guzmán ha de aparecer vestida de clarisa. La espiritualidad promovida por las órdenes mendicantes (especialmente por la orden franciscana), movió a muchos magnates del periodo a asumir su hábito en el momento postrero en busca de una buena muerte ${ }^{20}$. Sancho IV, por ejemplo, fallecido en 1295, asumió el hábito franciscano antes de morir, siendo amortajado con el mismo. Así fue representado en el sepulcro que mandó hacer la reina viuda doña María de Molina en 1309 en la capilla de los Reyes Viejos de la catedral de Toledo, del cual subsiste su imagen yacente. Su muerte y enterramiento marcan un hito en la difusión de esta práctica funeraria en la Corona de Castilla, donde se generalizó en el siglo XIV. Por eso es por lo que el sepulcro de doña Mayor Guillén de Guzmán resulta excepcional en la medida en que aporta un testimonio iconográfico de esta práctica funeraria en fecha tan temprana como 1276 (aun cuando esta práctica no se trasladase a la imagen yacente, donde, como veremos, doña Mayor aparecía retratada como la alta dama que fue). Este costado del sepulcro pudo completarse con una representación de la Anunciación, frecuente en contextos funerarios en tanto que, al ser imagen de la Encarnación, era el preludio necesario de la Redención. Así parece deducirse de la expresión E el ángel e la María que sean a cabeça de donna Mayor que, de forma un tanto oscura, se incluye al final de la descripción del costado de los pies (ciertamente, esta escena encontraría mejor acomodo espacial e iconográfico en la cabecera).

La excepcionalidad del sepulcro de doña Mayor Guillén de Guzmán viene subrayada por otro detalle que se precisa en el contrato a propósito de uno de sus costados mayores, aquel en que había de representarse la que hemos denominado "familia social y espiritual". Allí se pide que aparezcan también las estorias de Sant Francisco e de Sancta Crara, esto es, las efigies de los santos fundadores de la orden a la que pertenecía el convento patrocinado por doña Mayor. Si bien la presencia de frailes franciscanos formando parte de las ceremonias fúnebres es frecuente en los sepulcros de este periodo, incluso aun cuando el sepulcro se encargara para una casa ajena a esta observancia (aparecen, por ejemplo, en los sepulcros de doña Urraca López de Haro y de la Beata de Cañas), la presencia de los santos fundadores es inusual en fecha tan temprana (por ejemplo, en el ámbito burgalés no se documenta antes de la segunda mitad del siglo XV) ${ }^{21}$.

Sobre el sarcófago hasta aquí analizado, resguardado por el baldaquino anteriormente mencionado, se disponía la imagen yacente de doña Mayor Guillén de Guzmán que conocemos gracias al trabajo de Ricardo de Orueta (fig. 4), quien nos indica que su longitud era de 2,05 m. Esta imagen se ajustaba escrupulosamente a las prescripciones del contrato: que sea donna Mayor enleuada en la cobertura de la sepultura e que sea vestida muy noble de sus pannos de colores de oro e de azul e de carmín e de argent e de todas las otras colores que conuienen a la sepultura e que sea todo fino. Et en esta sepultura sobredicha a de auer dos ángeles enleuados a la cabeça e otros dos ángeles a los pies. Estos ángeles, de pequeñas dimensiones, se suelen interpretar en relación con la liturgia celeste de acogida del alma del difunto y menudearán en la plástica funeraria

\footnotetext{
${ }^{20}$ Núñez, 1987.

${ }^{21}$ Gómez Bárcena, 1988a: 35-36.
}

Arch. esp. arte, LXXXVIII, 349, ENERO-MARZO 2015, 37-52 ISSN: 0004-0428, eISSN: 1988-8511, doi: 10.3989/aearte.2015.03 
solo a partir de mediados del siglo XIV, si bien encuentran un preciso correlato en los sepulcros de doña Urraca López de Haro y de la Beata de Cañas que aquí se han esgrimido como término de comparación preferente con el sepulcro de doña Mayor Guillén de Guzmán.

En definitiva, el sepulcro que se encargó en 1276 para doña Mayor Guillén de Guzmán en el convento de Santa Clara de Alcocer aunaba rasgos excepcionales, como, para empezar, su propia tipología de sepulcro exento albergado por un baldaquino o como un desarrollo iconográfico en el que, junto a las recurrentes escenas de funerales, llamaban la atención su acento mariológico o su énfasis mendicante, que llevó a representar en uno de los relieves menores a su titular con el hábito franciscano y a incorporar a los fundadores de la orden a una de las escenas funerarias, con una íntima relación con otros grandes sepulcros del momento, lo cual hace tanto más lamentable que se desmantelara en fechas remotas y que desapareciera definitivamente en 1936.

\section{Hacia un perfil profesional de Juan González}

Todo este despliegue monumental e iconográfico se confía a un individuo, Juan González, que se presenta a sí mismo como el pintor de las imágenes de Burgos, el cual ha de ejecutar su labor en madera tallada y policromada, esto es, partiendo de unas competencias básicas que nosotros asociamos, más bien, al oficio de escultor, aun cuando somos conscientes de la importancia de la poli-

Fig. 4. Alcocer (Guadalajara), convento de Santa Clara: imagen yacente del sepulcro de doña Mayor Guillén de Guzmán († $c$. 1263); foto: Ricardo de Orueta (C) CSIC, Centro e Ciencias Humanas y Sociales, Biblioteca Tomás Navarro Tomás.

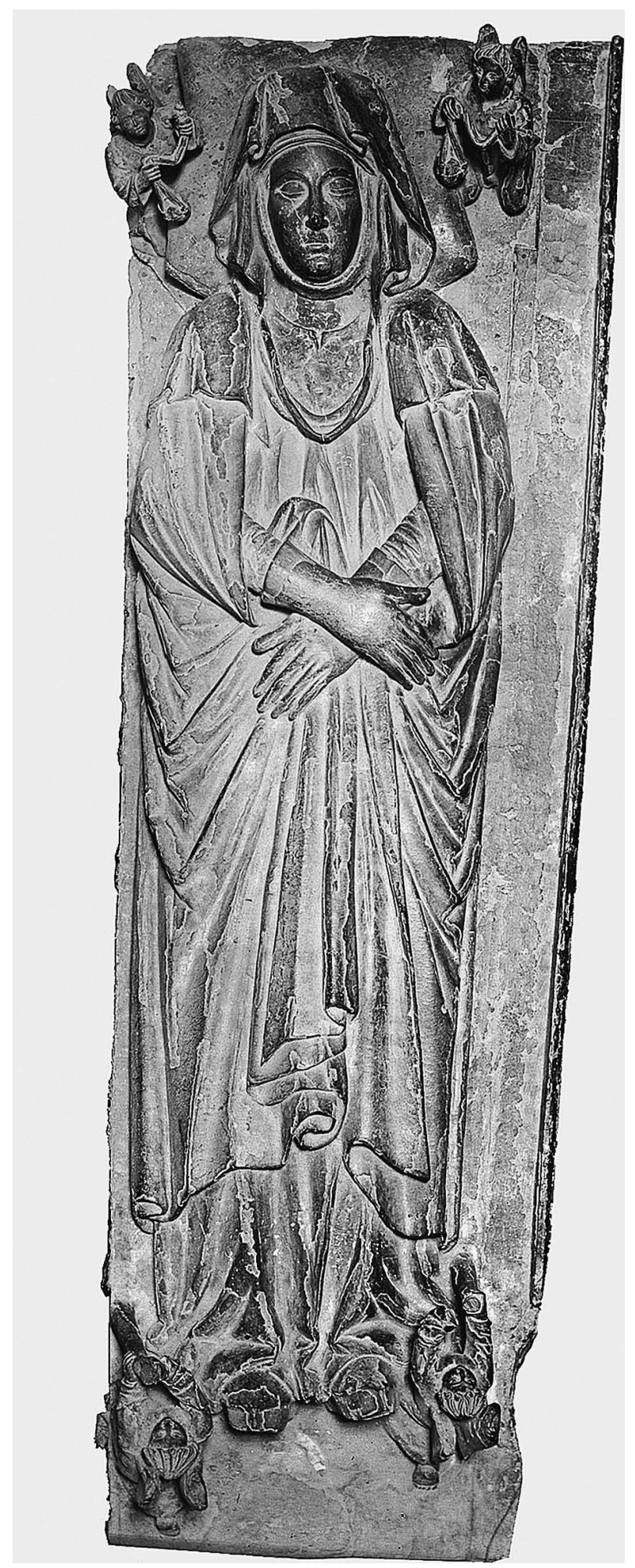

Arch. esp. arte, LXXXVIII, 349, ENERO-MARZO 2015, 37-52

ISSN: 0004-0428, eISSN: 1988-8511, doi: 10.3989/aearte.2015.03 


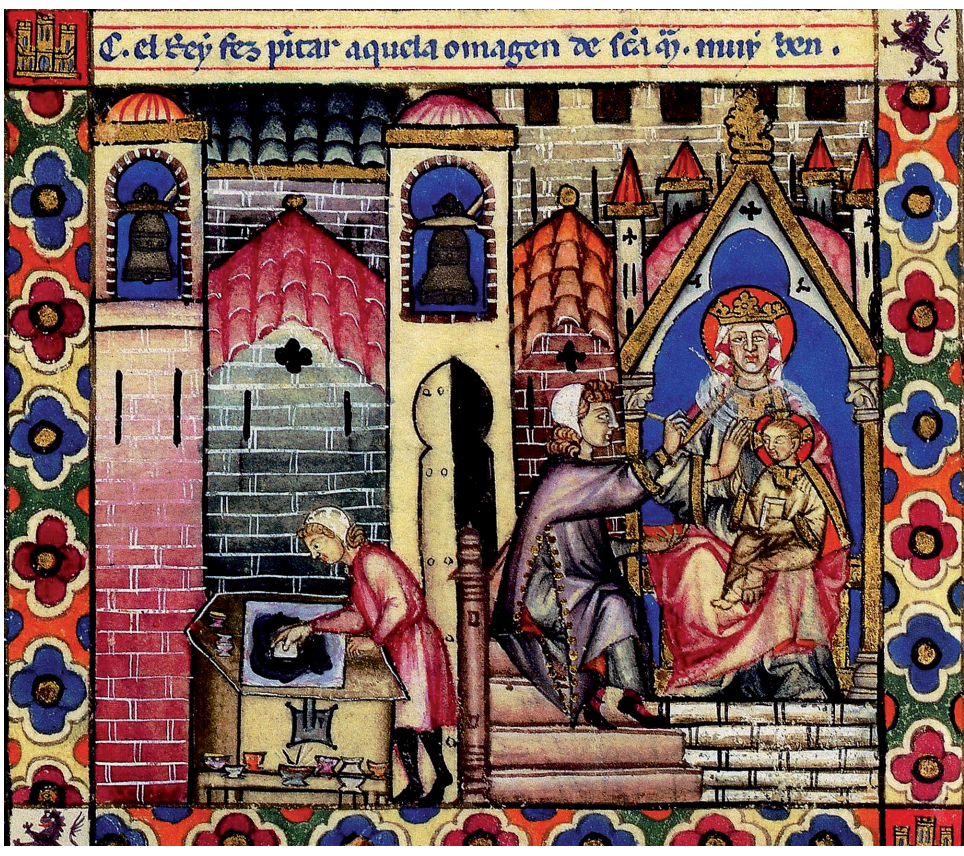

Fig. 5. San Lorenzo de El Escorial (Madrid), Real Biblioteca: ms. T.I.1 (Códice Rico de las Cantigas de Santa María), detalle del f. 192r (cantiga CXXXVI: Como el rey fez pintar aquela omagen de Sancta Maria muy ben); foto: edición facsímil.

cromía en el acabado de estas obras. Sin embargo, en la segunda mitad del siglo XIII el oficio de escultor presenta aún una cierta indefinición que, como en este caso, se refleja en el léxico y en los documentos. El llamado Livre des métiers d'Étienne Boileau, una colección de reglamentos de distintos oficios de París efectuada c. 1268, distingue entre el oficio de los imagiers-tailleurs, que realizan labores de talla en diversos materiales (en términos actuales podríamos denominarlos imagineros), y el oficio de los imagiers-peintres, encargados de enriquecer las imágenes con oro y con colores (esto es, doradores y policromadores) ${ }^{22}$. En esta copiosa suma ni existe un lugar para el pintor propiamente dicho ni queda claro el estatus del escultor que participa en proyectos monumentales (el imagier-tailleur trabaja d'os, d'yvoire, de fust et de toute autre maniere d'estoffe, quele que ele soit).

Podríamos estar tentados de ver en el "pintor de imágenes" castellano un equivalente del imagier-peintre parisino. Podríamos reconocer, incluso, a este profesional en la cantiga CXXXVI del Códice Rico de las Cantigas de Santa María (fig. 5). Sin embargo, el contrato que un individuo así denominado firma en 1276 en Burgos, con su copia de figuras enleuadas (esto es, en relieve), implica la asunción de labores estrictamente escultóricas que van más allá de lo que cabría esperar de algo parecido a un imagier-peintre. Seguramente, los límites en este momento entre escultura y pintura eran mucho más lábiles de lo que tendemos a imaginar. A veces la policromía exigía labores previas de modelado que matizaban la labor escultórica, por lo que, en la práctica, el pintor se veía obligado a actuar como un escultor. A la inversa, a veces las labores de talla se concebían $a b$ initio con una planitud que solo cobraría vida con la aplicación del color (pienso, por ejemplo, en algunos ejemplos primitivos de retablos castellanos de la segunda mitad del siglo XIII, como el que recientemente se ha incorporado al Museo Nacional del Prado a través de la donación Várez Fisa, los cuales, en realidad, no son muy distintos de sus correlatos pictóricos), por lo que el

${ }^{22}$ Lespinasse y Bonnardot (eds.), 1879: 127-130.

Arch. esp. arte, LXXXVIII, 349, ENERO-MARZO 2015, 37-52 ISSN: 0004-0428, eISSN: 1988-8511, doi: 10.3989/aearte.2015.03 
escultor se veía obligado a actuar como un pintor ${ }^{23}$. Pienso, en definitiva, que Juan González, bien fuera en su persona, bien fuera en su taller, reunía las dos especialidades, en lo cual no fue, probablemente, un caso único ni excepcional. Ahora bien, ¿por qué opta por presentarse entonces como "pintor de imágenes"?

La situación de los oficios artísticos en Castilla en la segunda mitad del siglo XIII fue magníficamente analizada por Rafael Cómez Ramos en su conocido estudio sobre las empresas artísticas de Alfonso X el Sabio ${ }^{24}$. Resultan significativos, asimismo, los estudios lexicográficos de María del Carmen Martínez Meléndez ${ }^{25}$. En estos estudios no falta la referencia a un Pero, pintor de ymagenes estrictamente contemporáneo de nuestro artífice ${ }^{26}$. En el periodo que nos ocupa el conjunto de habilidades propias del oficio de escultor era ejercido por el que documentos y testimonios literarios denominan entallador ${ }^{27}$. Sin embargo, el número de ocurrencias del término es relativamente escaso para lo que debió de ser la realidad del momento, siendo posible, según apuntan numerosos indicios, que la palabra pintor aludiera, en realidad, a menudo, al concepto de escultor (esto es, que se usase indistintamente para uno u otro oficio, aunque su empleo no implicase, necesariamente, el conocimiento o práctica de ambos oficios). En Carrión de los Condes el sepulcro pétreo del podestat don Álvar Fernández de Lara († entre 1239 y 1242) presenta la inscripción "Pedro pintor me fizo este mio monumento" 28 . Ya el erudito Carderera apostilló a propósito de este sepulcro que el apelativo de pintor "ni es apellido, ni significa lo que suena, porque esta palabra era común en aquel tiempo a todos los profesores de las tres Bellas Artes"29. La mayor riqueza documental de la Corona de Aragón permite constatar esta situación con mayor claridad. En Cataluña, junto a testimonios que apuntan, claramente, a la práctica de ambas especialidades por parte de ciertos artífices (quizás el caso más conocido sea el de Guillem Seguer), existen testimonios que indican, no menos claramente, que individuos que practican únicamente la escultura son denominados pintores. Quizás el caso más conocido sea el de Esteve de Burgos, pintor de la ciutat de Oscha (así en su primera ocurrencia documental, de 1357). Así pues, para la segunda mitad del siglo XIII no se puede establecer la ecuación pintor = pintor en el sentido moderno del término: a veces querría decir, en efecto, pintor, a veces, escultor y, a veces, artista capaz de practicar las dos especialidades, especialmente en piezas que requerían el concurso de ambas, como retablos, imágenes o sepulcros policromados: este podría ser el sentido específico de la expresión "pintor de imágenes", que parece haber tenido una entidad propia, claramente diferenciada de la de "pintor".

La documentación burgalesa de los siglos XIII y XIV, abundantemente publicada e indizada, nos pone ante un cierto número de pintores asentados en este periodo en la ciudad: Domingo Pascual (1241) ${ }^{30}$; Martín Ramiron (1298) ${ }^{31}$; Pedro González (1305) ${ }^{32}$; Fernando Fernández (1319)

${ }^{23}$ Esto ocurría, incluso, en la escultura monumental, como se pudo comprobar con ocasión de la restauración de la portada de la Majestad de la colegiata de Toro, v. Katz, 2002: 5, si bien a propósito de este caso Katz piensa que escultores y policromadores, que no serían sino pintores, sin mayor diferenciación, actuarían de manera independiente.

${ }^{24}$ Cómez Ramos, 1979: 1-61.

${ }^{25}$ Martínez Meléndez, 1995.

${ }^{26}$ Cómez Ramos, 1979: 49 y 55. Martínez Meléndez, 1995: 769. Se le documenta en el repartimiento de Murcia, donde aparece, asimismo, Pero Martínez, entallador, el cual pudiera ser el mismo individuo, que volvería a comparecer en la documentación murciana en 1295 como Pero Martínez, pintor, v. Cómez Ramos, 1979: 49. Martínez Meléndez, 1995: 743 у 774.

${ }^{27}$ Cómez Ramos, 1979: 45-47. Martínez Meléndez, 1995: 739-744.

28 Ara Gil, 1992: 26.

${ }^{29}$ Citado por La Viñaza, 1889: 114.

${ }^{30}$ Lizoain Garrido, 1985: 108-109 (núm. 329).

${ }^{31}$ Peña Pérez, 1983: 175-177 (núm. 114). Se le menciona junto con sus hijos Juan Ramírez y Sancho. Se le menciona póstumamente en 1356, v. Peña Pérez, 1983: 241-258 (núm. 150).

32 Castro Garrido y Lizoain Garrido, 1987: 342-343 (núm. 193).

33 Castro Garrido, 1987: 295-297 (núm. 351).

Arch. esp. arte, LXXXVIII, 349, ENERO-MARZO 2015, 37-52

ISSN: 0004-0428, eISSN: 1988-8511, doi: 10.3989/aearte.2015.03 
Domingo Ruiz (1345) ${ }^{34}$; Juan Rodríguez de Arcos (1345) ${ }^{35}$; Gonzalo González (1385) tínez $(1390)^{37}$. A esta nómina habría que añadir a Alfonso Esteban, pintor del rey, a quien se pagan en 1293500 maravedís para pintar la capiella de Santa Barbara de Burgos ${ }^{38}$, y quizás a cierto Garçi Perez de los Pintores, así denominado de forma un tanto confusa en $1319^{39}$. Contemporáneamente no comparece en la documentación burgalesa ningún entallador (no así otros oficios artísticos, como el de cantero, el de carpintero o el de orfebre), lo cual, unido a las consideraciones anteriormente efectuadas acerca del alcance en este periodo de la expresión "pintor", debería inducirnos a una cierta reserva acerca del verdadero perfil profesional de estos individuos.

Resulta llamativo, sin embargo, que Juan González se presente en el contrato de 1276 como el pintor de las imágenes de Burgos, con una formulación antonomástica y excluyente, como si no hubiese contemporáneamente otro artífice en la ciudad que practicase esta especialidad (lo cual, en una ciudad como Burgos y en un contexto cronológico como el de 1276, con las obras de la catedral y de las Huelgas a pleno rendimiento, parece, a priori, poco probable). En relación con esto debemos preguntarnos si se conservan otros trabajos que, a partir del contexto de su producción y del análisis de su estilo, se puedan atribuir a Juan González. Orueta, que desconocía la factura burgalesa del sepulcro, relacionó su estilo con el del taller leonés de la Virgen Blanca. Como es bien sabido, este taller deriva del taller burgalés de la puerta de la Coronería, que a mediados del siglo XIII introdujo en Castilla una versión del clasicismo gótico distinta del rigor de la puerta del Sarmental (enraizado en Amiens), más natural en sus formas plenas y en sus expresiones serenas, reinterpretando, probablemente, para ello, las propuestas clasicistas de Reims. Creo que el trabajo de Juan González se puede situar, en líneas generales, en esta orientación, pero creo, asimismo, que no cabe proponer una mayor aproximación de el pintor de las imágenes de Burgos a los talleres escultóricos catedralicios. Su obra carece del volumen y de la plasticidad que presentan las esculturas contemporáneas en el primer templo burgalés. En Juan González el tratamiento de los ropajes adolece de cierta sequedad y de carácter formulario (obsérvense, por ejemplo, los pliegues en forma de "V" del flanco del manto de doña Mayor Guillén de Guzmán), sin llegar a ser nunca tan copiosos como en sus contemporáneos catedralicios (fig. 6). Por otra parte, detalles como las cabezas de los ángeles, de apariencia un tanto deforme, o como sus sumarios peinados resultan abiertamente defectuosos, todo ello sin perjuicio de una obra en cualquier caso notabilísima que da lo mejor de sí en el rostro de la difunta y que entiendo que debía de confiar su espectacularidad a su diseño de conjunto y a su policromía. En definitiva, no parece que, a día de hoy, pueda asimilarse a Juan González a los talleres catedralicios ${ }^{40}$. ¿Se le puede relacionar con otras obras? Contemporáneamente la casa real estaría involucrada en la fabricación de dos sepulcros de infantes fallecidos en 1275: don Fernando de la Cerda en el monasterio de las Huelgas y doña Leonor en el convento de Santo Domingo el Real de Caleruega. Ambos sepulcros, que carecen de imágenes yacentes, presentándose, simplemente, como monumentales sarcófagos recubiertos por ricas telas, integraban labores escultóricas y pictóricas, pero el sepulcro de don Fernando, en piedra, incluye un Calvario relacionado con la escultura catedralicia que

${ }^{34}$ Peña Pérez, 1990: 297-299 (núm. 115).

35 Peña Pérez, 1990: 282-293 (núms. 110-113).

${ }^{36}$ Silva Maroto, 1990: I, 116-117. Habitaba unas casas del cabildo y había fallecido ya en 1414.

${ }^{37}$ García Aragón, 1985: 286-290 (núm. 154). Se le menciona como morador a Sant Martin y se indica que es hijo de Juan Martínez de Carrión. Es, quizás, el pintor de este nombre documentado entre 1414 y 1425, fallecido ya en 1426, v. Silva Maroto, 1990: I, 120.

${ }^{38}$ López Dapena, 1984: 434.

${ }^{39}$ Castro Garrido, 1987: 309-310 (núm. 357).

${ }^{40}$ Puede que resulte oportuno el cotejo de la obra de Juan González con la extraordinaria colección de imaginería del monasterio de las Huelgas. Un análisis reciente, acompañado de buenas reproducciones, se encuentra en Yarza Luaces, 2005: 23-33.

Arch. esp. arte, LXXXVIII, 349, ENERO-MARZO 2015, 37-52 ISSN: 0004-0428, eISSN: 1988-8511, doi: 10.3989/aearte.2015.03 
parece exceder de las posibilidades de Juan González y el sepulcro de doña Leonor, en madera, apenas ha conservado elementos significativos que permitan su comparación con el sepulcro de doña Mayor Guillén de Guzmán.

Por estos años se tallaban, asimismo, en Burgos algunos sepulcros de madera policromada que serían similares, en líneas generales, al de doña Mayor Guillén de Guzmán, sentando, de esta manera, las bases de una notable tradición escultórica cuyos especímenes mejor conservados datan ya del siglo XIV. Del siglo XIII se conservan parcialmente los de don Diego García de Villamayor ( $\dagger \mathrm{d}$. de 1286), procedente del monasterio cisterciense de Santa María la Real de Villamayor de los Montes ${ }^{41}$, y de don Sancho Sánchez Carrillo († d. de 1295), procedente de la iglesia de San Andrés de Mahamud, que incorporaba, incluso, paneles pintados con emblemas heráldicos, escenas de duelo e iconografía religiosa ${ }^{42}$. El primero, de especial calidad, se aproxima notablemente a los talleres catedralicios, distanciándose, en consecuencia, de las especificidades de Juan González. El segundo, de factura más seca y estilizada, tampoco parece fácilmente asimilable al estilo de el pintor de las imágenes de Burgos, que, en definitiva, no parece haber tenido la exclusividad que parece querer arrogarse con esta denominación.

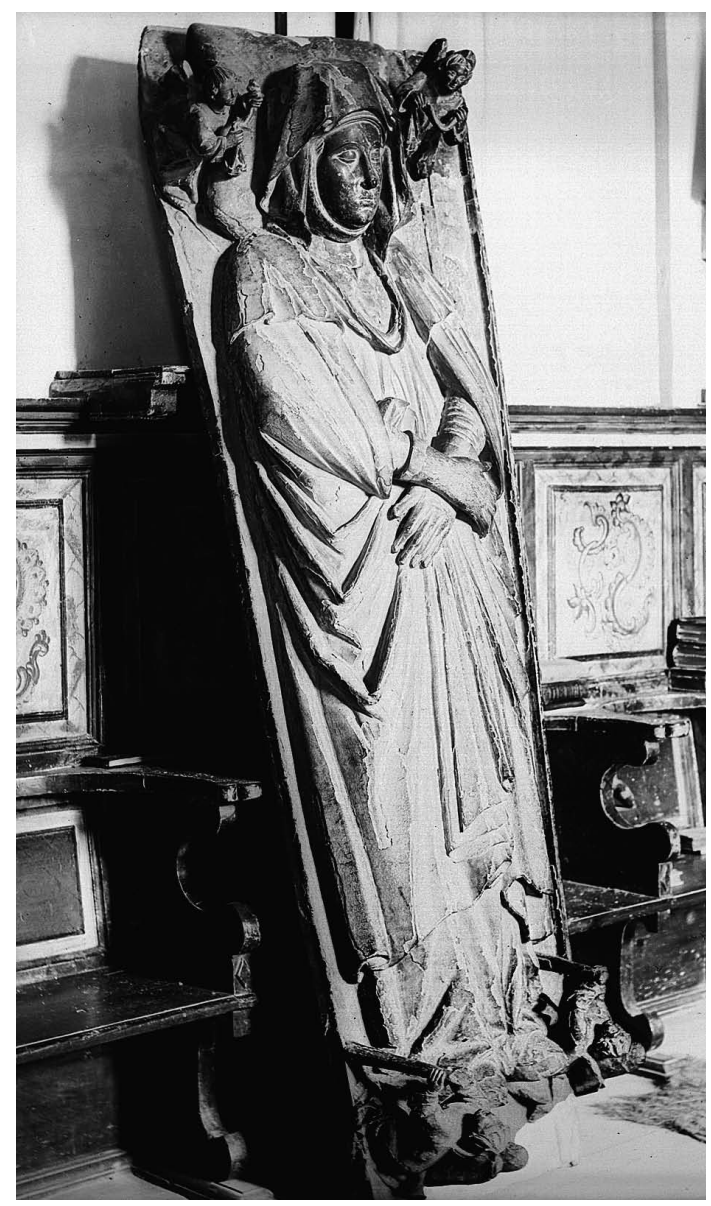

Fig. 6. Alcocer (Guadalajara), convento de Santa Clara: imagen yacente del sepulcro de doña Mayor Guillén de Guzmán († c. 1263);

foto: Ricardo de Orueta (C) CSIC, Centro de Ciencias Humanas y Sociales, Biblioteca Tomás Navarro Tomás. llén de Guzmán procedente del convento de Santa Clara de Alcocer que Christie's de Londres sacara a la luz en 2009 nos ha permitido asomarnos a la situación profesional de la escultura en Castilla en la segunda mitad del siglo XIII. Nos ha permitido, asimismo, conocer una de las obras sin duda más espectaculares producidas por entonces, superando tanto las traslaciones y transformaciones de que fue objeto a lo largo de los siglos como su presumible destrucción, causada por la Guerra Civil. Gracias a este documento, las fotografías que Ricardo de Orueta tomara a principios del siglo XX cobran nuevo sentido y vitalidad. Y el lugar que corresponde a esta obra en la historia de la escultura gótica española también.

\footnotetext{
${ }^{41}$ Cambridge (Massachusetts), Fogg Museum (núm. 1936.11), v. Gillerman (ed.), 1989: 174-175 (núm. 139).

${ }^{42}$ Cincinnati (Ohio), Cincinnati Museum of Art (núm. 1958.93), y Barcelona, Museu Nacional d'Art de Catalunya (núms. 4372, 4374 y 4375), v. Gillerman (ed.), 2001: 269-271 (núm. 204). Gutiérrez Baños, 2005: II, 101-109 (núm. 32).
}

Arch. esp. arte, LXXXVIII, 349, ENERO-MARZO 2015, 37-52

ISSN: 0004-0428, eISSN: 1988-8511, doi: 10.3989/aearte.2015.03 


\section{APÉNDICE DOCUMENTAL}

1276, julio, 24. Burgos. Contrato firmado entre Juan González, el pintor de las imágenes de Burgos, y don Juan Pérez, capellán de doña Beatriz, reina de Portugal, para la ejecución de un sepulcro de madera policromada para doña Mayor Guillén de Guzmán, madre de doña Beatriz, en precio de 460 maravedís.

Connosçuda cosa sea a todos los omnes quantos que esta carta vieren cómmo yo, Johán Gonçáluez, el pintor de las imágenes de Burgos, de / barrio de Sancta María Uieia Rúua, ffago atal paramiento con uusco, don Johán Pérez, el capelán de donna Beatriz, rreyna de Portogal, que uos $\beta^{\beta}$ ffaga vna sepultura toda de madera de nogal pora donna Mayor Guillem, madre de donna Beatriz, la sobredicha.

Esta sepul/tura a de ser ffecha en esta manera: que sea donna Mayor enleuada en la cobertura de la sepultura $e$ que sea vestida muy noble / de sus pannos de colores de oro $e$ de azul $e$ de carmín $e$ de argent $e$ de todas las otras colores que conuienen a la sepultura $/{ }^{6} e$ que sea todo fino. Et en esta sepultura sobredicha a de auer dos ángeles enleuados a la cabeça $e$ otros dos ángeles a los pies / $e$ a de auer $\mathrm{xxx}^{\text {ta }}$ personas enleuadas enderredor de la sepultura que empareien con donna Mayor $e$ a la cabeça de la sepultura / que sea la imagen de Sancta María e donna Mayor que sea a sos pies en oraçión e en el tabernáculo de suso que a de cobrir la sepultura $/^{9}$ el Cruciffiçión e la María $e$ el Johán $e$ dos ángeles. Et en el vna costera de la sepultura que sea la rreyna de Portogal $e$ sos fijos / $e$ donna Mayor en medio en su lecho $e$ todos vestidos de sus pannos. Et de la otra parte de la sepultura $e$ (sic) las estorias de Sant Francisco / e de Sancta Crara $e$ el abbadessa $e$ el conuento $e$ sus donzellas $e$ los de criazón $e$ donna Mayor en medio en su lecho $e /^{12}$ todos cubiertos de sus sennales. Et a los pies de la sepultura donna Mayor que yaga en so lecho cubierta de los pannos de la orden / de Sancta Clara $e$ dos ángeles a la cabeça quel' reciban el alma. $E$ el ángel $e$ la María que sean a cabeça de donna Mayor. $E$ VI leones / enleuados, tres de la vna parte $e$ tres de la otra, que tengan la sepultura ssobre ssí $e$ so tabernáculo que cubra la sepultura, que sean $/^{15}$ de colores pintados.

Esta sepultura sobredicha assí como sobredicho es otorgo que uos he de ffazer por quatro çientos $e$ sessaenta maravedís de / los dineros blancos que el rrey mandó ffazer en el tiempo de la guerra $e$ que me los dedes en esta guisa: los çient maravedís que me dedes a plazo del primero / día del mes de septiembre primero que uien e los otros çient maravedís que me dedes por la Sant Martín primera que uien e los otros çient maravedís por $/^{18}$ las Carrestoliendas primeras que uienen e los otros çient $e \mathrm{LX}^{\text {ta }}$ maravedís a plazo de la Pasqua de Rresurrecio Domini primera que uien.

Et sobresto yo, Johán Gon/çáluez, el sobredicho, só fiador $e$ debdor con todo quanto que yo he moble $e$ heredat por do que quier que lo yo aya $e$ abré de oy caba delant por dar / a uos, don Johán Pérez, capelán de donna Beatriz, 1[a] sobredicha, o a qualquier que esta carta mostrare en uuestra voz toda esta obra sobredicha dándo $/{ }^{21}$ me los sobredichos maravedís a los plazos sobredichos $e$ que uos dé toda esta obra sobredicha bie $n$ fecha e bien acabada a plazo de la Pasqua de Rresurrecio Domini / primera que uien. Et si a este plazo sobredicho non uos dó toda esta obra fecha $e$ acabada assí como sobredicho es, que uos peche todos quantos días passa/re de más del plazo cada día $\mathrm{v}$ maravedís por paramiento $e$ por postura de la moneda sobredicha fasta que uos lo dé fecho $e$ acabado dándome ${ }^{24}$ los maravedís a los plazos sobredichos. Et sobresto yo, don Johán Pérez, el sobredicho, só fiador $e$ debdor con todo quanto que yo he moble $e$ heredat por do que quier / que lo yo aya $e$ abré de oy caba delant por dar a uos, don Johán Gonçáluez, el pintor sobredicho, o a qualquier que esta carta mostrare en uuestra voz / todos estos quatro çientos $e$ Lx ${ }^{\text {ta }}$ maravedís sobredichos a los plazos sobredichos assí como sobredicho es en esta carta. Et si a estos plazos sobredichos ${ }^{27}$ non uos dó todos estos maravedís assí como sobredicho es, que uos peche todos quantos días passare de más de los plazos cada día otros v maravedís por paramien/to $e$ por postura de la moneda sobredicha fasta que uos dé estos maravedis sobredichos uos dándome la obra sobredicha fecha $e$ acabada.

Ffecha es esta carta en / Burgos en el mes de julio, sábado, a XXIIII días, anno Domini M. ${ }^{\circ}$ CC. $^{\circ}$ LXX. $^{\circ}$ VI. $^{\circ}$, era M. $^{a}$ CCC. ${ }^{a}$ XIIII. ${ }^{a}$. E desto son testigos que lo uieron e lo ${ }^{\beta 0}$ oyeron de omnes buenos de Burgos rogados de amas las partes don Pere de Montresín, don Bartolomé de Montresín, don Bernalt / Prouenzal, don Johán Domínguez, el de don Mathé Guillem, don Rroy García, ermano de donna Mayor, de la pica, Gonzalo Pérez, ermano / de don Pablo, el orebze. Yo, Petro Iohán, escriuano público de Burgos, fiz esta carta $e$ pus en ella mi sennal (signo).

Arch. esp. arte, LXXXVIII, 349, ENERO-MARZO 2015, 37-52 ISSN: 0004-0428, eISSN: 1988-8511, doi: 10.3989/aearte.2015.03 


\section{BIBLIOGRAFÍA}

Ara Gil, Clementina Julia (1992): "Un grupo de sepulcros palentinos del siglo XIII. Los primeros talleres de Carrión de los Condes, Pedro Pintor y Roi Martínez de Burueva". En VV.AA., Alfonso VIII y su época, actas del II Curso de Cultura Medieval (Aguilar de Campoo, 1990), Madrid, Centro de Estudios del Románico, pp. 21-52.

Arbesú, David (2013): “Alfonso X el Sabio, Beatriz de Portugal y el sepulcro de doña Mayor Guillén de Guzmán”. En eHumanista, vol. 24, Santa Barbara (California), pp. 300-320.

Castro Garrido, Araceli (1987): Documentación del monasterio de las Huelgas de Burgos (1307-1321), Burgos, Ediciones J. M. Garrido Garrido.

Castro Garrido, Araceli y Lizoain Garrido, José Manuel (1987): Documentación del monasterio de las Huelgas de Burgos (1284-1306), Burgos, Ediciones J. M. Garrido Garrido.

Cómez Ramos, Rafael (1979): Las empresas artísticas de Alfonso X el Sabio, Sevilla, Diputación Provincial.

García, Juan Catalina (1899): Biblioteca de escritores de la provincia de Guadalajara y bibliografia de la misma hasta el siglo XIX, Madrid, Establecimiento Tipográfico "Sucesores de Rivadeneyra".

García Aragón, Lucía (1985): Documentación del monasterio de la Trinidad de Burgos (1198-1400), Burgos, Ediciones J. M. Garrido Garrido.

García de Paz, José Luis (2011): Patrimonio desaparecido de Guadalajara, $2^{a}$ ed., Guadalajara, AACHE Ediciones.

García Marsilla, Juan Vicente (2009): "El precio de la belleza. Mercado y cotización de los retablos pictóricos en la Corona de Aragón (siglos XIV y XV)". En Denjean, Claude (ed.), Sources sérielles et prix au Moyen Âge. Travaux offerts à Maurice Berthe, Toulouse, CNRS-Université de Toulouse-Le Mirail, pp. 253-290.

García Martín, Francisco (2009): El patrimonio artístico durante la Guerra Civil en la provincia de Guadalajara, Guadalajara, Diputación.

Gillerman, Dorothy (ed.) (1989): Gothic Sculpture in America I. The New England Museums, Nueva York y Londres, Garland Publishing.

Gillerman, Dorothy (ed.) (2001): Gothic Sculpture in America II. The Museums of the Midwest, Turnhout, Brepols.

Gómez Bárcena, María Jesús (1988): Escultura gótica funeraria en Burgos, Burgos, Diputación Provincial.

Gómez Bárcena, María Jesús (1988): "La liturgia de los funerales y su repercusión en la escultura gótica funeraria en Castilla”. En Núñez, Manuel y Portela, Ermelindo (coords.), La idea y el sentimiento de la muerte en la historia y en el arte de la Edad Media, Santiago de Compostela, Universidad, pp. 31-50.

González Jiménez, Manuel (2004): Alfonso X el Sabio, Barcelona, Editorial Ariel.

González Jiménez, Manuel y Carmona Ruiz, María Antonia (2012), Documentación e itinerario de Alfonso X el Sabio, Sevilla, Universidad.

Gutiérrez Baños, Fernando (2005): Aportación al estudio de la pintura de estilo gótico lineal en Castilla y León: precisiones cronológicas y corpus de pintura mural y sobre tabla, 2 ts., Madrid, Fundación Universitaria Española.

Herrera Casado, Antonio (1997): Monasterios medievales de Guadalajara, Guadalajara, AACHE Ediciones.

Katz, Melissa R. (2002): “Architectural Polychromy and the Painters' Trade in Medieval Spain". En Gesta, vol. XLI/1, Nueva York, pp. 3-13.

La Viñaza, conde de (Cipriano Muñoz y Manzano) (1889): Adiciones al diccionario histórico de los más ilustres profesores de las Bellas Artes en España de don Juan Agustín Ceán Bermúdez, t. I (Edad Media), Madrid, Tipografía de los Huérfanos.

Lespinasse, René de y Bonnardot, François (eds.) (1879): Les métiers et corporations de la ville de Paris. XIII siécle. Le livre des métiers d'Étienne Boileau, París, Imprimerie Nationale.

Lizoain Garrido, José Manuel (1985): Documentación del monasterio de las Huelgas de Burgos (12311262), Burgos, Ediciones J. M. Garrido Garrido.

López Dapena, Asunción (1984): Cuentas y gastos (1292-1294) del rey D. Sancho IV el Bravo (1284-1295), Granada, Publicaciones del Monte de Piedad y Caja de Ahorros de Córdoba.

Martín Prieto, Pablo (2002-03): “Origen, evolución y destino del señorío creado para la descendencia de Alfonso X de Castilla y Mayor Guillén de Guzmán (1255-1312)”. En Temas Medievales, vol. 11, Buenos Aires, pp. 219-240.

Arch. esp. arte, LXXXVIII, 349, ENERO-MARZO 2015, 37-52

ISSN: 0004-0428, eISSN: 1988-8511, doi: 10.3989/aearte.2015.03 
Martín Prieto, Pablo (2005): "La fundación del monasterio de Santa Clara de Alcocer (1252-1260)". En Hispania Sacra, vol. LVII, Madrid, pp. 227-241.

Martín Prieto, Pablo (2005): El monasterio de Santa Clara de Alcocer en la Edad Media, Guadalajara, Diputación.

Martín Prieto, Pablo (2007): "Sobre la promoción regia de la orden franciscana en la Corona de Castilla durante el primer reinado Trastámara”. En Hispania Sacra, vol. LIX, Madrid, pp. 51-83.

Martín Prieto, Pablo (2010): "Un catálogo-inventario del archivo del monasterio de Santa Clara de Alcocer, en Massachussets". En Wad-al-Hayara, núms. 35-36-37, Guadalajara, pp. 21-58.

Martínez Meléndez, María del Carmen (1995): Estudio de los nombres de los oficios artesanales en castellano medieval, Granada, Universidad.

Martínez y Sanz, Manuel (1866): Historia del templo catedral de Burgos escrita con arreglo a documentos de su archivo, Burgos, Imprenta de Don Anselmo Revilla.

Núñez, Manuel (1987): “La indumentaria como símbolo en la iconografía funeraria". En Fragmentos, núm. 10, Madrid, pp. 72-84.

Orueta, Ricardo de (1919): La escultura funeraria en España. Provincias de Ciudad Real, Cuenca, Guadalajara, Madrid, Centro de Estudios Históricos.

Peña Pérez, Francisco Javier (1983): Documentación del monasterio de San Juan de Burgos (1091-1400), Burgos, Ediciones J. M. Garrido Garrido.

Peña Pérez, Francisco Javier (1990): Documentación del monasterio de las Huelgas de Burgos (1329-1348), Burgos, Ediciones J. M. Garrido Garrido.

Pérez Arribas, Andrés (1974): Alcocer. Historia y arte, Guadalajara, s. e..

Relaciones topográficas de España. Relaciones de pueblos que pertenecen hoy a la provincia de Guadalajara con notas y aumentos de D. Juan Catalina García, académico de número (Memorial Histórico Español, t. XLI) (1903): Madrid, Establecimiento Tipográfico de la Viuda e Hijos de M. Tello.

Ruiz Maldonado, Margarita (1996): "Escultura funeraria del siglo XIII: los sepulcros de los López de Haro". En Boletín del Museo e Instituto “Camón Aznar”, LXVI, Zaragoza, pp. 91-169.

Sánchez Ameijeiras, Rocío (1993): Investigaciones iconográficas sobre las escultura funeraria del siglo XIII en Castilla y León, Tesis Doctoral, Universidade de Santiago de Compostela.

Silva Maroto, María Pilar (1990): Pintura hispanoflamenca castellana: Burgos y Palencia. Obras en tabla y sarga, 3 ts., Valladolid, Junta de Castilla y León.

Yarza Luaces, Joaquín (1984): “Despesas fazen los omnes de muchas guisas en soterrar los muertos”. En Fragmentos, núm. 2, Madrid, pp. 4-19.

Yarza Luaces, Joaquín (2005): "Monasterio y palacio del rey". En Yarza Luaces, Joaquín (comisario), Vestiduras ricas. El monasterio de las Huelgas y su época 1170-1340, cat. exp., Madrid, Patrimonio Nacional, pp. 15-34.

Fecha de recepción: 06-II-2014

Fecha de aceptación: 06-VI-2014

Arch. esp. arte, LXXXVIII, 349, ENERO-MARZO 2015, 37-52 ISSN: 0004-0428, eISSN: 1988-8511, doi: 10.3989/aearte.2015.03 